\title{
Directed Metalation of Ester-Substituted Indolizines
}<smiles>[R]OC(=O)c1ccn2ccccc12</smiles><smiles>[R]OC(=O)c1c(C(Cl)Cl)cn2ccccc12</smiles>

\section{dynamic} equilibrium<smiles>O=C(O)c1ccn2c([N+](=O)[O-])cccc12</smiles>

THF, $0{ }^{\circ} \mathrm{C}, 30 \mathrm{~min}$ $\downarrow \mathrm{E}^{+}$<smiles>O=C(O)c1ccn2c(F)cccc12</smiles><smiles>O=C(O)c1c(F)cn2ccccc12</smiles>

Selected examples:<smiles>CCOC(=O)c1ccn2c(I)cccc12</smiles>

$80 \%$ yield<smiles>CCCCOC(=O)c1ccn2c(I)cccc12</smiles>

$85 \%$ yield<smiles>CCOC(=O)c1ccn2c(C=O)cccc12</smiles>

$79 \%$ yield<smiles>CCCCOC(=O)c1ccn2c(C=O)cccc12</smiles>

$69 \%$ yield<smiles>CCOC(=O)c1ccn2c(Cl)cccc12</smiles>

$72 \%$ yield<smiles>CCC(C)(C)OC(=O)c1ccn2c(Cl)cccc12</smiles>

$62 \%$ yield

\section{Key words}

metalation

magnesium

indolizines
Significance: Clososki and co-workers report a directed $\mathrm{C}-\mathrm{H}$ functionalization of 1-ester-substituted indolizines using several organometallic bases. The metalation takes place under mild conditions, and the reaction with different electrophiles allows the synthesis of a number of polyfunctional indolizines in good yields.
Comment: Lithium amides favor $\mathrm{C}-5$ functionalization, while TMPMgCl-LiCl gives C-2 substituted derivatives as major products by ortho metalation. The authors found that in the case of functionalization with TMPMgCl$\cdot \mathrm{LiCl}$, the reactivity of the electrophile plays a key role in the regioselectivity of the reaction. 